\title{
Corporate Governance in Manufacturing and Management with Analysis of Governance Failures at Enron and Volkswagen Corporations
}

\author{
Moses Jeremiah Barasa Kabeyi \\ Department of Mechanical and Manufacturing Engineering, University of Nairobi, Nairobi, Kenya \\ Email address: \\ mkabeyi@uonbi.ac.ke, moseskabeyi@yahoo.com
}

\section{To cite this article:}

Moses Jeremiah Barasa Kabeyi. Corporate Governance in Manufacturing and Management with Analysis of Governance Failures at Enron and Volkswagen Corporations. American Journal of Operations Management and Information Systems. Vol. 4, No. 4, 2019 , pp. $109-123$. doi: 10.11648/j.ajomis.20190404.11

Received: June 25, 2019; Accepted: August 27, 2019; Published: January 4, 2020

\begin{abstract}
Good corporate governance is important in management of all organizations. It gives direction to an organization in matters of accountability, integrity and quality of product and service offerings in the wake of stiff competition and conflicting stakeholder interests. Business challenges and realities create conditions that favor governance failure through unethical conduct hence the need for regulations in addition to self-governance. Business ethics in business and manufacturing helps organizations in making ethically critical decisions. Corruption is a significant indicator of governance failure and involves illegal activities, criminal activities that are both financial and non-financial abuses and benefits. Corporate governance should provide a framework upon which organizations are hence creates order and harmony between various stakeholders. Good corporate governance improves organization's image as a self-policing institution that is responsible and honest. Whereas self-regulations looks more attractive for free market economies, legislation and control is necessary since not all managers believe and act within good corporate governance. The board of directors should set the strategic objectives and provide leadership for realization and supervise the management and report to shareholders on their leadership. The Enron Corporation and Volkswagen scandals demonstrated that severe consequences result from failed corporate governance in form monetary and non-monetary that affect both perpetrators and the innocent. Where corporate governance fails, major indicators include, manipulation of financial records, corruption, poor quality products and exaggerated quality specifications in manufacturing and engineering, high staff turnover, lack of transparency and accountability, poor stakeholder relationship, poor performance and low economic development leading widespread poverty and social disorder. External enforcement should be considerate to genuine stakeholder interests to avoid legislation that will encourage cheating for survival. Perpetrators of governance failure, should be punished both as individually and as organizations to set an example to others in the form of penalties that are reasonably high to discourage noncompliance.
\end{abstract}

Keywords: Corporate Governance, Code of Ethics, Business Ethics, Corruption, Volkswagen Scandal, Emission Levels Scandal, Corporate Reputation, Corporate Scandal, Enron Scandal, Ethical Failure

\section{Introduction to Corporate Governance and Business Ethics}

Corporate governance refers to rules, processes, and practices that are enforced to direct and control a company or organization. It should take care of the interests of all stakeholders, namely shareholders, employees, community, regulatory authority, suppliers, government and all with interests in the organization. Corporate governance is needed to ensure success and sustainability of an organization over time in the course of its operations. History of corporate world has witnessed manipulations and scams in business practice. These frauds are often widespread, expensive, and multifaceted and have effects on all stakeholders. Good corporate governance should be structured in a way that prevents conflict of interest through incentives as well as checks and balances that ensure the board and management 
to pursue organizational objectives at the expense of personal objectives. The first well-documented securities fraud, known as the 'Dutch Tulip Mania' dates back 1636 and 1637 in the Netherlands. Whenever corporate frauds take place, the corporate world is slapped with either new governance structures or new ones are put in place together with, codes and guidelines [1]. This means that the consequences will always be felt by many and that the problem of corporate governance started many years ago.

Ethics, anti-corruption profile, and corporate governance practices are significant considerations when making business decisions particularly related competitive advantage, financial performance and investment decisions. Globalization has been the major driving force behind the rapid development of good corporate governance practices and standards. The bottom line is that corporate governance plays a critical role in controlling. All stakeholders including investors, shareholders, the media, regulators, citizen and general public, should play their role in ensuring good corporate governance succeeds in both business and government. For private sector development to flourish, especially for the small and medium scale sectors, anticorruption effort must be effective, vigilant and constant without failure [34]. Therefore corruption is a result as well as indicator corporate governance failure in organizations and society and should be controlled

The global importance of corporate governance became clear in 2002 following several governance failures arising from fraud, and other unethical and criminal conduct that led to loss of shareholder wealth and investment loss, job losses and pain to employees and family, tedious criminal investigation and legal proceedings, and imprisonment of culprits or perpetrators leading to increased legislation and control at the expense of self-regulation. Common governance failures include creative accounting where false financial reports are provided, fraud, theft and others [24]. Ethical values are those values that identify or define things that are acceptable or are morally right [7]. Therefore values can be good or bad, acceptable or unacceptable. It is these values that lay the foundation of good corporate governance besides institutional arrangements that enhance transparency and accountability in corporate leadership and management. On his part, he [5] defines business ethics as conduct that provides guidance to the decision making process and function within an organization in business context. According to the study [15] ethical issues are very important for both organizations and individuals. Unethical activities and conduct have proved to be quite costly to organizations with consequences that include defrauding organizations or employees, consumers, creditors, and even the government. The author recommends that organizations should create ethical environments through role modelling and consistent and predictable decision making on issues of ethics and morality so as to give direction and avoid ethical dilemmas in the organizations. Kabeyi advises that there are long term corporate and individual gains for acting ethically in business undertakings and that organizations and individuals should act ethically in the course of business operations and conduct. Therefore business ethics forms the framework upon which decisions and actions are made in an organization for corporate governance to be realized. The paper [5] advises that good business ethics is a necessary condition for good corporate governance to develop and therefore good ethical conduct is desirable for successful business activities. He recommends that ethical considerations and decisions be made during strategy formulation and implementation as well as evaluation since they have consequences on business, both positive and negative. We can therefore observe that it is hard to separate good corporate governance and ethical values and principles of managers as well as employees of the organization, both individually and as institutions.

\subsection{Business Ethics}

From the business perspective, ethics refers to principles and standards that guide human behavior in the conduct of business operations and activities. Businesses should strike a balance between the need to maximize profits and conflicting needs of other stakeholders. This calls compromises to be made to strike a balance between conflicting interests. For these to be realized, rules that are both declared and implicit are needed to guide the businesses to generate profits without harming or infringing on rights and welfare of other individuals or society as a whole [26]. Business ethics is the expected standard of how a business should operate and gives guidelines to stakeholders like customers, employees, directors, shareholders, government and others with the objective of avoiding conflict [38]. Therefore the main objective of business ethics is to eliminate conflict between stakeholders with conflicting interests in business practice.

The field of business ethics arose in the 1970s and slowly gained acceptance as an academic discipline and practice over time. Business ethics is temporal, and therefore the guiding principles that arise may vary over time and so tend to change over time and place. These is because as some principles remain concrete, tradition or norms tend to vary over time and place. The result is that some practices that are acceptable today may become unacceptable in future as circumstances change. Technology has not been spared by this changes, for example when the automobile industry first arose, burning more fuel to generate more power output was embraced, but now concerns over efficiency and global warming hence need to minimize emissions is the more acceptable standard globally. There are those who argue ethical constraints are unnecessary and harmful to business practice and manufacturing. These opponents to business ethics believe that the progress of organizations is impeded through constraint and, as such, the advancement of the corporation toward its goals are restricted [26]. This argument postulates that society as a whole suffers as progress, medical, technical or otherwise is interfered with or curtailed. Whereas this position sounds extreme, case studies on governance failure suggest otherwise. According to the study [12] only $30 \%$ to $80 \%$ of top level management believe that a corporation has an obligation to do well by society in 
addition to making shareholder's more money. This confirms the need for regulation alongside self-regulation in issues or corporate governance. This implies that business realities and challenges may create circumstances that tempt managers to engage in unethical conduct leading to governance failure and serious consequences.

\subsection{Regulation and Corporate Governance}

At the end of the 20th century, there was widespread loss of confidence in businesses and organizations to self-govern themselves. This was as a result of several cases of governance failure witnessed. A number of scandals shook the business world and reduced investor confidence. As a result, the United States House and Senate enacted the Public Company Accounting Reform and Investor Protection Act also known as the Sarbanes-Oxely Act of 2002. The Sarbanes-Oxely Act laid the legal obligations for publicly traded organizations and also privately held corporations, with the objective of improving accountability to the public and stakeholders. The same happened in Canada with the enactment of Bill C-198. Key Oversight issues outlined in this act included objective mandates such as auditor independence, more or enhanced disclosurs and accountability for criminal fraud, as well as well as corporate responsibility. Sarbanes-Oxely and C-198 acts placed the responsibility for steering corporate governance firmly on the board of directors and top management of the organizations. Corporations became legally obligated to follow a course of social compliance with regulation and control falling on the Securities and Exchange Commission. Attempts by some organizations to engage in conflict with what is socially acceptable to the majority of people or stakeholders are checked by legal imposition of accountability enforced through state machinery [24]. It is therefore evident that the need for legal imposition of accountability and hence external regulation of business was a result of corporate scandals and governance failures that had reached alarming levels not just in the united states but globally. This is undesirable to investors who prefer self-regulation as opposed to imposed or external controls.

\subsubsection{Ethics Versus Law}

The law and ethics are not one and the same thing, but the law can guide ethical behavior like through Sarbanes-Oxely by laying out a framework. Ethicists argue that the law should be thought of as the bare minimum of an ethical framework. Complying with the law and behaving ethically are not necessarily synonymous. While Sarbanes-Oxely and C-198 Acts specifically state that destroying evidence or fraudulent behavior is illegal, they do not state the series of questionable decisions that lead to the fraud is as well. To guide the behavior of the corporation, management must turn to the field of business ethics. In the case of Volkswagen, the execution of the deceptive computer program at the EPA emissions test laboratory is where the law was broken, while punitive fines and penalties were direct consequences. The work that preceded that breach and the culture of deception that brought it to fruition constitutes breach of ethical principles according to social standards [24]. Therefore law is not sufficient to control or prevent ethical misconduct, instead it should be regarded as the minimum measure to prevent governance failure.

\subsubsection{Descriptive and Normative Directives in Ethics}

Philosophically, ethics has got different fields of study which include normative ethics which focuses on what is right and wrong and so it is generally concerned with application of moral codes in decision making. Descriptive ethics, on the other hand, seeks to understand or explain an underlying moral belief or principle about an issue under consideration. The field of business ethics is principally focused on steering an organization to do what is considered right. Business ethics is therefore principally normative in nature. The field of business ethics attempts to guide corporations in making ethically difficult decisions [24].

\subsection{Corruption and Business}

Corruption is the ultimate outcome of poor corporate governance. According to Transparency International as cited in the study [35], corruption involves abuse of power entrusted upon an individual or official for private or individual gain. Key elements of corruption are;

i). Corruption applies equally to private sector, public sector or government and civil society sector.

ii). It refers to both systematic and individual abuses that range from illegal activities, criminal activities as well as just unethical acts.

iii). Corruption involves both financial and non-financial abuses and benefits.

iv). Corruption demonstrates the importance of governance systems in controlling as well as regulating the practice and exercise of authority.

v). Corruption leads to misallocations, mismanagement and shifting of resources from intended use leading to poor performance of companies, organizations and economies.

Whereas corruption is damaging as individual or systemic, the latter is more damaging since it is difficult to detect and control [34].

\subsubsection{Effects of Corruption}

According to the research [34] the effects of corruption include;

i). It undermines property rights of individuals and organizations.

ii). Corruption weakens institutional capacity to perform effectively and efficiently.

iii). It discourages investment as a result of increased cost of investment and risks.

iv). Corruptions weakens rule of law and governance systems

v). It limits private sector growth and hence wealth creation and employment.

vi). Limits political development and democracy which 
may lead to political unrest and instability.

\subsubsection{Cost of Corruption}

The practice of corruption comes with huge costs. It is costly to entire society, organizations and individual. According to the study [34], the costs include;

i). Wasteful resources use as a result of misallocations

ii). Leads to reduced competition, efficiency and innovation in the market as corruption rent seeking culture and favoritism which leads to high prices for low quality and reduced product and service offerings in the market.

iii). Corruption scares local and international investors leading to reduced investment and even withdrawal of investment and hence negative growth.

iv). Corruption leads to high levels of unemployment, increased crime and suffering as private and public investments which create jobs and markets are hampered.

v). Corruption leads to unresponsive or undesirable policies and power administration as lawmakers and planners favor rent seekers instead of the general citizenry and leaders are not held accountable.

\subsection{Corporate Governance}

The term corporate governance is derived from the latin word 'gubernare' meaning to drive or steer. These implies that corporate governance is concerned with the direction function of an organization [14, 19]. According to Youssef [39] corporate governance a framework upon which organizations are directed and controlled. It consists of the rules, regulations and norms which clarify how the various stakeholders of the organization relate to one another. According to the study [30], corporate governance is the methodology used by organizations to police itself. It is the way an organization governs itself just like a sovereign state through their own laws, policies, procedures and customs. Sun noted that the purpose of corporate governance is to increase accountability in its functions within itself and with third parties or stakeholders. Corporate governance provides a structure through which management systems are set and sensationalized. So, corporate governance provides a framework upon which organizations are controlled and, managed.

Corporate governance can also be said to be the economic, institutional and legal framework upon which an organization is directed and controlled on daily basis [13]. It is concerned with rules and principles of organizational direction which ought to include imposition of strict rules, checks and balances to guide operations and business conduct [14, 19]. These checks and balances ensure transparency, responsibility and accountability in business practice [30]. Therefore corporate governance creates order and harmony in organizational leadership between stakeholders.

According to the study [27] effective corporate governance should include guidelines civil or criminal prosecution of individuals and corporates who conduct unethical or illegal acts in the name of organizations. There should also be a code of ethics meant to provide guidance. Therefore Good corporate governance should provide rules and regulations that the government and organization but in addition to ethics and the values which drive companies in the conduct of their business.

Where there is good corporate governance, organizations have board of directors that are in charge of the governance of the organizations. In addition, the shareholders appoint directors and auditors and ensure that the organization has in place effective governance structures. The board of directors set the strategic objectives and provide leadership for realization and supervise the management and report $g$ to shareholders on their leadership. The board's operations are guided by laws, regulations and the shareholders. In the total relationships, there should be balance between individual and community goals with the aim of aligning them as nearly as possible [34]. Therefore for good corporate governance, the board of directors should be in charge of overall leadership and direction of the organization.

\subsubsection{Objectives of Corporate Governance}

In realization of corporate governance, the following objectives are pursued according to Yadav (nd.);

i). Built trust and confidence between stakeholders with compelling and conflicting interests.

ii). Enhance shareholder value and stakeholder interest in product and service offerings of the organization.

iii). To develop and effective, efficient and transparent system of information and communication for timely provision of all necessary information.

iv). Avoid losses, damages and conflict of interest including litigation, penalties, and prosecutions. Therefore the objective of good corporate governance is good citizenship that obeys laws and regulation.

\subsubsection{Principles of Corporate Governance}

There are several principles that underlie corporate governance. According to the paper [27], these principles include;

i). There is transparency and accountability to promote trust. These comes with reliable financial records and overall reporting.

ii). There exists a board of directors with clearly spelt responsibilities and guidelines.

iii). There should be a code of ethics for all stakeholders

iv). Respect for interests of all stakeholders of the organization.

v). Respect for laws governing the operations of the company in conduct of business.

vi). Respect for the voice and will of shareholders who exercise their powers and rights of electing directors and auditors.

vii). Ethical violations should be investigated and punished for all involved.

These principles and characteristics of good corporate governance can be summarized as integrity, fairness, accountability and responsibility. 


\subsubsection{Benefits of Corporate Governance}

There are several benefits that result from good corporate governance. According to the study [12], these benefits include;

i). Substantial improvement in business process that include internal controls and decision making.

ii). It makes easier and faster realization of business strategies like acquisitions and mergers due to increased standardization and accuracy of records

iii). Corporate governance leads to an institutionalization of organizations hence less or no dependence on an individual to run the business. This guarantees business or organizational sustainability beyond current ownership or leadership.

iv). Corporate governance leads to higher investor confidence hence makes it easy to raise risky but necessary capital and financing. Through this it is possible to diversify the capital structure leading to decreased cost of capital and hence more profits for the business and organizations.

v). Leads to more recognition of stakeholders including national and international institutions hence improved partnerships and working relations.

vi). Good corporate governance leads to higher market valuation of the company and this leads to increased value to shareholders.

vii). Good corporate governance attracts and retains talent in the organization. This guarantees strategy consistency and improved performance due to existing corporate stability.

\subsubsection{Good Corporate Governance Practices}

Several measures can be put in place to enforce or guarantee good corporate governance. According to the study [12] an organization should consider several governance measures but identifies the following as popular measures in the eyes of shareholders, investors, regulatory authorities and other stakeholders;

i). Development of governance policies including code of conduct and ethics

ii). Have a functioning board of directors and establish relationship with executive managers. This is necessary because the board of directors is the core of governance in organizations.

iii). Strengthen shareholder rights who then play an important role through voting to elect directors and make key corporate strategic decisions. The shareholders constitute and perform the democratic function of the organization.

iv). Improve the internal control environment with clear role of an independent external auditor who checks systems and operations to make a fair and balanced opinion for improvement.

v). Develop a transparency and disclosure policy of information to facilitate timely, accurate, sufficient disclosure essential for shareholders, potential investors, regulatory authorities and other stakeholders

vi). Institute measures to guarantee business sustainability like strategic planning and management.

\section{Corporate Governance Failure}

\subsection{Background of Corporate Governance}

Corporate failure of an organization refers to its inability to conform to its set standards of expectations and plans, financial obligations, as well as ethical expectations and targets set. A corporate failure is highly undesirable because it destabilizes the economic, social and financial setups and hence should be avoided or averted through different ways [1]. It is because of these consequences that corporate governance should avoid put in place measures to avoid failure.

\subsection{Causes of Governance Failure}

Causes of governance failure include week laws and regulations touching on ethical requirements, lack of code of ethics guiding conduct, poor role modelling for new leaders, inconsistent decisions and policy on ethical issues, lack of training and failure to monitor employees performance based on ethical standards and requirement [15].

Where employees, directors or stakeholders are involved in conflict of interest, unethical issues are bound to arise. So there is need to encourage employees and other stakeholders to suppress conflict of interest and whenever it arises in the cause of their work, this should be declared as a matter of policy [15]. On his part [11] argues that the factors that enhance or facilitate unethical conduct include environmental factors in that the environment may encourage or promote unethical practices for example pressure of work, competition and tight time schedules can force individuals, employees and leaders or managers to engage in unethical, illegal and unacceptable conduct so as to be safe or survive.

The causes of governance failure are many as identified by the studies [2, 15] can be listed as follows;

i). leadership experience and focus

Several organizations are managed by directors and managers without training or experience in critical aspects of corporate governance hence they lack commitment and focus to it leading to more interest in profitability, cost management and control with no regard to governance issues. These means that the organization has little or no attention to culture issues from the top level management and leadership. This lack of focus and objectives on governance then permeates down through the organization, perpetuating conflict, chaos and confusion for all stakeholders at in the organization hierarchy.

ii). Confusion over the role of good governance versus excellence

It is unfortunate that many institutions do not appreciate that that governance is a business philosophy that requires a total change in attitudes and practices by all stakeholders in the organization. They instead assume that good governance 
is about compliance with external laws, controls and requirements. So all they do is work hard to comply and nothing more than that. Obviously this is not what corporate governance is all about. Governance demands a culture of excellence in all our undertaking, both internal and external to the organization.

iii). Lack of commitment in time and resources

Most organizations underestimate the time required, effort required and resources involved in making good governance work as part of the culture. They expect quick fixes and cheap investments which is not the case in reality. This is because positive change needs continuous commitment.

iv). Economic Distress

Poor economic state or downturn is one of leading causes of corporate failures, in many businesses, sectors or industry. A bad state of the economy may lead to the reduction in the activities, financial pressure and struggle for survival which adversely affects the performance of many firms in the economy. This could lead to unethical practices to survive the pressure.

\section{v). Mismanagement}

Mismanagement means lack or weakness in management control over the working of the employees and other business activities in an organization. It is mainly as a result of lack of managerial skills and capability, lack experience, in terms of strategic leadership, lack of teamwork, poor coordination, as well as lack of foresightedness, which then results in the failure of the enterprise to properly govern itself.

vi). Technological Causes

With the advancement in the technology, new modes of doing business has been introduced, which is better than the traditional ones. If an industry fails to employ the latest information and production technology, then the chance of failure of the firm may increase.

vii). Working Capital Problems

An organization with liquidity challenges, often fails to execute the day to day operations of the organization to the required standard creating an environment conducive for unethical conduct from within.

viii). Fraudulent Management

Some managers a simply greedy and this exposes an organization to corporate malpractice. Such like managers have a tendency to engage in fraud, regardless of circumstances. Such like managers will use unfair means such as falsification in the financial reports and accounting statements of the company to realize their objectives.

Therefore the known causes of governance failure are deliberate in some cases while in some, it is the operating environment and personal weaknesses for the institution as well as individual employees and managers.

\subsection{Symptoms of Corporate Failure}

Corporate governance failure may lead to disastrous consequences as realized by companies like Volkswagen, Enron, Cadbury, Xerox, Walmart, and many others. It should however be realized that governance failure does not happen overnight or instantly. There are signs that can be read prior to failure [1]. A number of indicators or signs can be used as a sign of corporate governance failure. They include;

i). Low profitability or losses from operations

ii). High Gearing

iii). Low Liquidity and hence inability to carry out critical functions.

iv). Ineffective governance like lack of board of directors or an ineffective committee of the board.

v). Lack of independence of a board or committee e.g. a CEO controlling all board functions.

vi). A management that circumvents internal controls and fails to accurately report and account for its actions to auditors or regulators.

vii). Inadequately qualified members of special committees or functions like audit.

viii). Ignorance or lack of regulations from regulators to oversight or identify red flags.

\subsection{Systemic Failure of Corporate Governance}

In some cases, we have total governance failure in a country or industry which is systemic failure. Governance failure can take various forms namely, regulatory governance failure, market governance failure, stakeholder governance failure and internal governance failure. According to the study [34] systemic failure of corporate governance means the failure on the whole set of regulatory governance, market governance, stakeholder governance and internal governance. This often leads to a crisis or total failure of a market or industry.

A good corporate governance system in a free market economy should have systemic integration of regulatory, market, stakeholder and internal governance. There must me a synergy of the various governance systems for proper management and governance in a free market economy.

\subsection{Common Corporate Governance Failures}

There are a number of common governance failures or omissions which contribute to corporate governance failure. According to the research [1], governance failures include;

i). Failure of internal audit

ii). Failure of audit committee

iii). Ineffective board of directors

iv). Delayed action by regulators.

\subsection{Criminal Actions in Corporate Governance}

Individuals and corporates commit the following governance related offences which can lead to various corporate failure consequences;

i). Forgery

ii). Falsification of documents

iii). Bribery

iv). Misappropriation of funds or theft

v). Conspiracy

vi). Breach of trust

vii). Obstruction of justice

viii). Money laundering 
ix). Mismanagement of organizational functions and activities.

x). Insider trading

xi). Round trip trading

\subsection{Main Players and Repercussions in Enron Scandal}

The main players implicated in most corporate scandals include the chairmen, Chief executive officers, auditors, top executives and chief finance officers. The repercussions of corporate scandals are imprisonment of perpetrators, monetary penalties like fines, bankruptcy, loss of employment through redundancies or sackings, mergers and takeovers and loss of investments and savings by investors [1].

\section{Enron Corporation as a Case of Business Ethics Failure}

\subsection{Background}

Enron Corporation depicted itself as a very successful company globally only to come to an abrupt collapse. This collapse affected thousands of employees and shook the entire business community and public globally. At its peak, Enron was worth $\$ 90.75$ per share but when the firm was declared bankruptcy on December 2, 2001, they were trading at a mere $\$ 0.26$. This incident to date raises questions on how a great business, of the time in US collapsed almost overnight and how it took so long for regulators to discover unethical acts and scandals [8, 29].

\subsection{Enron's Energy Origins}

Enron Corporation was formed in 1985 as a product of a merger between Houston Natural Gas Company and Omahabased InterNorth Incorporated. The first CEO and Chairman was Kenneth Lay, who was the Chief Executive officer of Houston Natural Gas. Lay rebranded Enron Corporation into an energy trader and supplier. Company as a result of deregulation of the energy markets. This created a job opportunity where companies could place bets on future prices. Enron took of this opportunity and engaged in the business. In 1990, Lay created Enron Finance Corporation and appointed Jeffrey Skilling, from Mckinsey \& Company consultant, to head the new corporation [29].

Additionally, Enron created Enron Online (EOL) in October 1999, with an electronic trading website that focused on commodities. Effectively, Enron was the counterpart to every transaction on Enron Online and was party as either the buyer or the seller. Enron offered its reputation, credit, and expertise in the energy sector to win investors and customers in large numbers. The company was praised for its expansion and ambitious projects, and as a result of this development it was named America's most innovative company by Fortune for six consecutive years between 1996 and 2001 [29]. This is really significant success and enviable success.

For the first 15 years, Enron enjoyed great business success by transforming itself into the greatest energy corporations in the US market. As a result of the success, the company diversified its operations into electricity and later stated a joint business with Blockbuster Video to develop futures trade for new internet bandwidths. By mid-2000, EOL transactions were about $\$ 350$ billion in trade per year. In another subsequent investment Enron built high-speed broadband telecom networks and of millions of dollars were invested. However the company got near zero returns. With the recession in 2000, Enron got exposure to the most turbulent market forces. The effect was that, many investors and creditors started losing their investment [7, 29]. Therefore the beginning point of Enron collapse was investment in volatile market segments and failure to employ due diligence while making investments.

Then came fall 2000 and Enron Corporation started to crumble forcing CEO Jeffrey Skilling to start hiding the financial losses of the trading business and other operations using the so called mark-to-market accounting in which the value of a security is measured based on its current market value instead of its book value. Whereas this strategy can work in securities trading, it can be disastrous for actual businesses as in the case of Enron Corporation. Enron would build an asset like a power plant, and immediately claim the projected profit on its books. In cases where revenue from the project was less than the projected amount, instead of taking the loss, Enron would transfer the asset to an off-thebooks corporation where the loss would go unreported. The mark-to-market practice led to schemes that were designed to hide the losses and make the company appear more profitable than it really was. To control or manage rising losses, Andrew Fastow, chief financial officer from 1998, could show that the company was in financially sound yet subsidiaries were crushing under huge real losses [29].

Even with all this scheme ongoing, come 2001 and Enron Corporation was listed as the 7th Fortune 500 Company in the fortune survey portraying corporate success by then which any organization and management will work hard to maintain yet all was false. However by the end of the year 2001, Enron got exposed and was forced to file a bankruptcy protection since it could no longer sustain operations and had been falsifying its performance for long By 2003, the company became bankrupt and had many of its top leadership investigated for accounting fraud that lead to the discovery of the corporate scandal at Enron [7]. This case demonstrates that cheating or falsification of financial records to show good performances will not last forever.

\subsection{Ethical Failure of Enron Corporation}

Several reasons accounted for corporate governance at Enron Corporation. These according to the studies [7, 8, 32] include;

1) The business of futures market trading in which Enron was engaged is very risky and requires huge capital and debt financing to remain in business. This huge debts put a lot of stress and strain on management and hence the temptation to become unethical and engage in fraud 
by manipulating records and false reporting of business results.

2) High expectations from stakeholders like creditors, investors and customers put undue pressure on an organization. Since creditors are very keen on the balance sheet the executives at Enron showed a good asset to debts ratios to please creditors by removing huge amounts of debt from the balance sheet. This ensured that creditors kept funding operations and investors remained happy and positive, so all this was to maintain credit inflows through false reporting.

3) The auditors at Arthur Anderson had conflict of interest and wanted to keep their income from Enron by not revealing the truth to stakeholders and shareholders as a result of which they chose to be unethical to retain their business.

4) The Enron president created huge pressure on his employees to give high profits no matter the circumstances and fired up to $15 \%$ of his staff for failure to produce expected profits. A typical transaction al leader, Jeff Skilling, the president of Enron created a conducive environment for stressed and insecure workers to act unethically by falsifying accounts.

5) The board of directors at Enron had directors from different institutions with good governance records and had a clear written code of ethics to prevent fraud wherever they came from. On the other hand Enron had a code of Ethics and conduct but all these directors instead voted to suspend Enron's code of ethics to entertain fraud and falsehoods in accounting.

6) Executives at Enron used off-balance-sheet special purpose vehicles (SPVs), a known as special purposes entities (SPEs), hide debts and bad assets from stakeholders. The purpose of the SPVs was to hide accounting realities rather than operating results thus misleading the public and investors [29].

\subsection{Effects of the Scandal}

According to [7], the Enron scandal had several negative effects both at organizational and individual levels. These effects include;

1) 1. Andrew Faslow, who was Chief Finance Officer and architect of Enron's accounting tricks fraud was jailed for 6 years by a US court.

2) Enron shareholders lost sixty three billion dollars in total value of stock. This is huge loss of investment, a personal loss to innocent investors who relied on the false accounting reports certified by auditors.

3) Over twenty thousand employees at Enron lost jobs as well as another ninety thousand employees and partners at Arthur Anderson accounting firm as a direct result of this scandal. These employees lost their jobs, careers, income and livelihood for themselves and family.

4) Enron customers in their millions at California suffered power blackouts and huge electricity bills as a result of collapse of Enron, a company they developed partnership with for their energy solutions.
5) Companies had to do with tough regulations and highly regulated environment as a reaction to Enron's scandal which led to a new act which in itself is a source of bureaucracy in business operations and hence undesirable in a free market economy where selfregulation should hold.

6) Shareholders lost total $\$ 74$ billion in the four years leading up to Enron's bankruptcy.

7) In June 2002, Enron was found guilty of obstructing justice for destroying financial documents and records to defeat justice. This conviction was however overturned on appeal; but, the firm remained deeply disgraced by the scandals and dwindled into a holding company. Some former partners bought the name in 2014, creating a firm named Andersen Global. Enron was no more.

8) In 2006, CEO Jeffrey Skilling was convicted of conspiracy, fraud, and insider trading and received initially received a 24-year sentence, but this was reduced to 10 years in 2013. Skilling was required to give $\$ 42$ million to the victims of the Enron fraud and to cease challenging his conviction as part of the deal. To date but, Skilling remains in prison and is scheduled for release on February 21, 2028 [29].

Whereas the perpetrators of the Enron scandal were punished, other stakeholders suffered huge monetary and personal losses. Enron's collapse and the financial crisis brought new regulations and legislation to enhance accurate financial reporting by publicly trading companies. In July 2002, President George W. Bush signed into law the Sarbanes-Oxley Act which heightened the consequences for destroying, altering, or fabricating financial statements, and for trying to defraud shareholders (Segaw, 2019).

Enron's collapse became to be the biggest corporate bankruptcy to ever hit the financial world beating others like WorldCom failures and others like Lehman Brothers, and Washington Mutual governance failures. Increased regulation and oversight have been enacted to help prevent corporate scandals of Enron's magnitude.

Some companies are still facing the damage caused by Enron scandal. In March 2017, a Toronto-based investment firm was allowed to sue Jeffrey Skilling, Credit Suisse Group AG, Deutsche Bank AG, and Bank of America's Merrill Lynch unit over losses incurred by purchasing Enron Corporation shares [29]. These demonstrates that Enron scandal is yet to die many years later. Therefore unethical business conduct is quite expensive for it has a serious negative effect on all stakeholders and the economy as a whole.

\section{The Volkswagen Scandal}

\subsection{Introduction to Volkswagen Scandal}

Automotive emissions are a significant contributor to environment pollution and from greenhouse gas emissions which lead to global warming and health issues. In response to this scenarios, various countries have put in place stringent 
environmental controls whose aim is to at limit emission of these harmful products like oxides of nitrogen, Sulfur dioxide and other greenhouse gases. These measures put in place are costly and unfavorable to many businesses whose primary motive is to maximize profits for shareholders and other benefits for other stakeholders. In the US, the Environmental Protection Agency (EPA) developed emission controls to be met by all car manufacturers on nitrous oxides and other pollutants. All seemed to going on well with enforcement until the end of 2015 when automotive industry was shocked by announcement of the unethical conduct by Volkswagen Corporation with regard to these pollution control measures and limits in its bid to bypass them. This is what came to be the Volkswagen scandal, a scandal that shook the automotive industry and regulators globally who put in place measures and penalties that proved very costly to Volkswagen and a number of employees involved in the scandal.

\subsection{Background of the Scandal}

On September 18, 2015, The Environmental Protection Agency (EPA) of US gave an announcement accusing Volkswagen of illegally installing a software in its diesel engine cars whose role was to manipulate the level of emissions during engine emission testing. In this case Volkswagen used the software to turn on the full emissions control systems for the vehicle only during testing for emissions. During other times, the vehicles were operating, with emissions control system turned off hence no pollution control. The software was programmed such that it would turn on the emissions control systems only when the car was running in a stationary position since that would be the condition when the car was being tested for emissions by regulators [31]. This discovery was done by The International Council of Clean Transportation (ICCT) research organization which was researching on diesel vehicles. The ICCT is a nonprofit environmental institution whose membership included former EPA officials. ICCT wanted to test the emissions of vehicles in the United States since the EPA has more stringent emission standards than in Europe. As a result, the original goal of tests was to try and "shame" the European automakers by proving to them that more stringent emissions standards as guided by EPA do not limit the overall performance of the vehicle as it had been demonstrated by Volkswagen. In this endeavor, ICCT partnered with researchers from West Virginia University to test the Volkswagen vehicles for emissions

However, during tests, the organization discovered that Volkswagen vehicles had different emission levels when tested with the car stationary than when the car was driven on the road [7]. This was a deliberate attempt by Volkswagen to cheat the United States Environmental Protection Agency (EPA) with respect to nitrous oxide engine emission developed by TDI diesel engines. The tested engines emission exceeded limits meaning 11 million vehicles worldwide had the problem. The immediate effect was negative publicity which affected the company's publicly traded market leading to $€ 14$ billion in losses during the fallout. These scandal ignited a serious debate on business ethics [22]. The EPA observed that when the full emissions control system had been turned off, the vehicle could release up to 40 times as much of the pollutant nitrogen oxide than is allowed under the Clean Air Act. These was dangerous because Nitrogen oxide is a catalyst in the development of ozone and smog and is associated with to a number of health issues including respiratory problems [31].

Volkswagen was also been involved in other unethical conduct. It was reported that in 2014, the firm had taken the lead in an experiment on 10 macaque monkeys to test the health impact of exposure to nitrogen dioxide $\left(\mathrm{NO}_{2}\right)$, which is toxic. A Volkswagen Beetle car, fitted with a cheat device used in the pollution scandal, pumped fumes into the monkeys' chambers as officials they watched cartoons. It was also revealed that in 2015 an automotive lobby group partfunded by Volkswagen tested the effects of $\mathrm{NO}_{2}$ exposure on 25 healthy young people in Germany [36]. These cases point at a company ridden with unethical behavior and probably was one of the bases upon which the emission scandal took root.

\subsection{Causes of the Volkswagen Scandal}

According to Mansouri [22] the Volkswagen chairman explained that the main reason for the scandal was an issue of mindset in some departments which fail to comply with set rule and regulations. The Chief Executive Officer of Volkswagen told law makers that only few employees took part in the scandal and that it was not a sanctioned by the company. However external investigation by law firm Jones Day, showed that fifty (50) members of staff most of whom were from Wolfsburg confessed that they knew about the emission scandal activities. It then emerged later that some Volkswagen engineers and technicians reported to supervisors about emission cheating in the year 2011, but this was ignored [3]. It was revealed on October 7, 2015 that the Chief Executive of Volkswagen's American division, Michael Horn, was actually aware of the emissions problems in the spring 2014. Horn was also told that Volkswagen engineers would work with the Environment Protection Agency in order to resolve the issue [18]. This shows that top management was aware of the noncompliance with EPA regulations.

The main reason for tampering was that Volkswagen had just developed a new diesel engine which did not meet EPA standards of pollution emissions. The development had come with investment of huge resources that needed to be recover. The EA engine that was developed took a long period of time and targeted a wide market not just Volkswagen vehicles, but other vehicles like Audi, Skoda and Seat. The engine was developed as part of the clean diesel engine marketing campaign used globally to convince customers that the vehicles that were environmentally friendly even with high mileage per gallon and strong physical performance. Instead of stating all over again with a new engine development, the managers decided to tamper with the actual emissions level. Before the introduction of the EA 189, Volkswagen had 
developed an alternative emission reduction technology with Daimler who makes Mercedes-Benz vehicles. This alternative technology was more expensive and in 2007, Volkswagen announced it was going to develop its own technology to reduce emissions [9].

According to [31] one of the reasons why Volkswagen set the emission control system to turn off is that it increases the power of the engine in areas such as torque and acceleration.

Therefore the main motive behind the scandal was tough emissions regulations as set by EPA and the need to maintain the overall vehicle efficiency during acceleration and high load conditions. This conflict together with ethical failures led to the Volkswagen scandal. According to Bob Lutz, former vice president of General Motors Corporation [31] remarked that there is a conflict in implementing emission reduction because emission technology is such that reducing output of nitrogen oxide automatically increases production of soot particles which are also pollutants and as such emissions technology is not able to reduce all harmful emissions. He also didn't understand how Volkswagen results could not be matched by General Motors engineering. These clears demonstrates the need to have tandem between technology and legislation.

According to the studies [9, 31], a top technology executive at Volkswagen made a presentation on how Volkswagen could manipulate emission results and went ahead to reveal that the company was rejecting any recommendation to improve existing emissions. Equipment in order to meet the tough US regulatory requirement. This could have been motivated by underestimation of potential cost of violating the regulation based on advice from a law firm which indicated that the maximum was US\$ 100 million. This was probably guided by the penalty against HyundaiKia for greenhouse gases emission violation involving 1.1 million cars which was $\$ 100$ million.

The decision making process should be clear as a way of enforcing corporate governance principles. It was also observed that the system of governance at Volkswagen had challenges. The study [31] observed that Volkswagen decision making process was too much centralized at the corporate headquarters making it too slow to respond and act on penitent issues related to the company.

\subsection{Consequences of Volkswagen Scandal}

The Volkswagen scandal brought severe consequences which according to the studies [4, 23, 26, 37] included;

i.) Volkswagen Chief executive Mr. Martin Winterkorn quit in 2015 soon after the emissions scandal was announced. This is a cost $t$ to the company and the officer was replaced by the head of Volkswagen's Porsche division, Matthias Müller. Such like changes are often costly.

ii.) Nine managers were suspended for taking part in emission scandal soon after the scandal was reported. This is enough to cause significant business disruption.

iii.) On September 21, 2015, the Justice department of
US government announced that it had commenced criminal probe into Volkswagen's use of software to manipulate nitrogen oxide levels during emission testing.

iv.) Increased public and congressional scrutiny at a time when the automobile industry was facing turbulence worldwide.

v.) On September 22, 2015, the company announced that up to 11 million vehicles globally had the emissions control software and allocated allocate a $\$ 7.27$ billion charge to its earnings to resolve the issue.

vi.) On September 20, 2015, Volkswagen announced that it had suspended all sales of the four-cylinder TDI diesel engine vehicles in the United States.

vii.) The scandal had financial implications as the company announced that its October 2015 global sales decreased by 5 percent due to the scandal.

viii.) The scandal caused Volkswagen lose $35 \%$ of stock value within one week of the scandal discovery or 29 Billion Euros in market capitalization which translates to a loss of 140 Euros in market value for each Euro of "savings" by not incorporating the emissions reduction technology in their vehicles.

ix.) The Environmental Protection Agency threatened to withhold approval on the 2016 Volkswagen and Audi models. This forced Volkswagen to admit to the tampering of the emissions exposing the company to a possible fine of up-to $\$ 37,500$ for each vehicle hence $\$ 18$ billion based on the number of cars that were fitted with software. This is a huge financial cost for any company.

x.) On March 29, 2016, the Federal Trade Commission (FTC) filed a complaint against Volkswagen for falsely advertising its diesel vehicles as environmentally low levels of emissions which was in compliance with environmental standards yet they are not.

xi.) On April 21, 2016, Volkswagen announced that it was going to fix or buy back all of the approximately 500,000 diesel cars in the United States yet they had only allocated $\$ 7.6$ billion for global costs of the emission scandal, which is a huge budget deficit for the company.

xii.) In early 2017, Volkswagen's bill for the scandal was about \$ 15.7 billion and still growing while combined for US and Europe was about US\$ 50 billion.

xiii.) The Volkswagen CEO Mr. Mathias Müller had pressure to return the company profitability and regain the needed public trust by stakeholders.

xiv.) When rigging in diesel emission test was revealed to the public, the sales significantly reduced. As a measure to cope with crisis, the company announced reduction of bonus of senior management.

xv.) A medical estimate showed that if Volkswagen did not recall vehicles with defeat device, then from 
2015 onwards, the cost on life would be 140 premature deaths. In addition, health cost of $\$ 840$ million will be caused by the Volkswagen diesel cars.

xvi.) On the environmental impact, excess of nitrogen oxide to the natural environment by Volkswagen diesel cars could results in acid rains which has negative impact on human health as well as cause destruction on nature and natural resources through the acidic action.

xvii.) On personal employee liability, Volkswagen suspended Ulrich Hackenberg, who was the head of development for all Volkswagen Group brands, Heinz-Jacob Neusser, who was head of development of the Volkswagen brand, and Wolfgang Hartz who was the head of engines and transmissions development for all of the Volkswagen brands. Loss of such expertise was a huge loss for any company to experience or go through.

\section{Measures to Prevent Corporate Governance Failure}

\subsection{Ethical Policy to Prevent This Scenario from Occurring in the Future}

According to the study [15], Illegal and unethical conduct by organizations and individual employees can impose huge costs on businesses $i$ and society and so should be avoided. Kabeyi argues that ethical solutions to business challenges may have multiple solutions which should be pursued preferably simultaneously by organizations and leadership. According to the studies $[11,15]$, to create an ethical organization the following can be done;

i.) There should be a policy of open communication between workers, managers and all stakeholders and this should be clearly stated and communicated to all stakeholders.

ii.) Ethics should be clearly stated as an organizational value and should be enforced in all in all undertakings with employees of the organization.

iii.) There should be a training program on ethics for all employees in the organization on ethical issues and conduct.

iv.) All leaders should undertake the responsibility of instilling positive ethical behavior in subordinates.

v.) There must be commitment to ethical behavior and conduct across the entire organization from the top management to the shop floor level.

vi.) The leadership of organizations should act as role models in as far as ethical leadership is concerned through their conduct and actions at work on day to day basis. So leaders should as a matter of policy be compelled to demonstrate to the employees on how to conduct business ethically.

vii.) Ethical issues should be entrenched as one of the elements in employee and leadership

viii.) Performance appraisals should have elements of ethics for continuous review.

According to the research [32] a code of ethics should be developed and enforced for all employees, board of directors as well as other stakeholders in an including executives. This code should be reinforced consistently in all decisions and guidelines within the organizations for them to take root. This according to the paper [15] will guide employees from cases of ethical dilemmas since they will have a clear understanding of what the organizations stands for on issues of ethical issues in business.

Whereas Enron had a code of ethics for the board it was disregarded and the directors watched as breaches were committed by the executives. As a confirmation of this, investigators confirmed that the board resolved to disregard the code of ethics yet it is the board and top management which should act as role models.

\subsection{Leadership Choices to Prevent Failure of Corporate Governance}

According to the studies [21] organizations should go beyond just being good at execution but instead develop reliable products through innovation and competitive strategy to realize higher sales competitively and sustainably. It is necessary to design organizations that have the ability to operate in a complex competitive global environment.

The leadership at Enron for should have been transformational in nature and not transactional. If they chose to be transformational Enron leadership would have prepared their employees to face the new challenges in new ways and keep the company afloat $[16,28]$. Instead of these, the company leadership decide to cheat and stick to the lie. It never worked for long, the tricks came to an end.

As a leaders the Board of Directors at Enron should have decided to walk the talk, instead, they disregarded the code of conduct and ethics. Why have a code of conduct which should be followed and you disregard it only to pay for your sins? An organizational culture should be developed which encourages honesty and transparency so that executives are rewarded or are made to see value in honest business. Stakeholders including employees, shareholders, and customers also need to appreciate that there is need to have honest business and income so that unnecessary pressure is not exerted on executives and employees forcing then to engage in unethical conduct. There must also be internal mechanism to punish dishonesty and leadership should do this consistently so that everybody in the organization develops positive ethical attitudes.

The operating environment for employees has a bearing on corporate governance. The workers should not be subjected to unrealistic targets which can force them to engage unethical practices to remain in employment or meet targets. This can be realized by enforcing qualitative targets and enforcing transformational leadership style [5]. And to avoid unnecessary pressure in business, Enron should engage in less risky business through innovations. 


\section{Observations and Recommendations}

Business challenges and realities at times create conditions that favor governance failure through unethical conduct hence the need for regulations in addition to self-governance. Therefore law is not sufficient to control or prevent ethical misconduct, instead it should be regarded as the minimum measure to prevent governance failure. The field of business ethics is principally focused on steering a corporation towards doing right and away from doing wrong. It is therefore principally normative in nature. Corruption which is abuse of power for personal gain in organizations is a sign of governance failure and involves illegal activities, criminal activities as well as just unethical acts in conduct of business and involves both financial and non-financial abuses and benefits. Effects of corruptions go beyond an organization to affect the entire country or economy and should therefore discouraged. Principles and characteristics of good corporate governance are can be summarized as integrity, fairness, accountability and responsibility. For this to be realized corporate governance should provide a framework upon which organizations are controlled and, managed. Therefore corporate governance creates order and harmony in organizational leadership between stakeholders. Therefore rules and regulations constitute important elements of good corporate governance. Therefore for good corporate governance, board of directors should be in charge of overall leadership and direction of the organization.

There are several causes of governance failure, and they include week laws and regulations, lack of code of ethics guiding conduct, poor role modelling for new leaders, inconsistent decisions and policy on ethical issues, lack of training and failure to monitor employee's performance based on ethical standards and requirements. Business pressure and stiff competition which at times may be unfair in nature may put a lot of pressure on organizations and management to the extent of creating an environment conducive for unethical, illegal or unacceptable conduct.

In the process of enforcing compliance, penalties are very important tools of enforcement. The $\$ 100$ million penalty for Hyundai-Kia based on violations involving 1.1 million cars was viewed as small and so it did not motivate Volkswagen to modify its emissions equipment to comply with regulations. This was based on the legal advice that Volkswagen received from its lawyers. Looks like Volkswagen would rather pay penalties, than incur extra losses so as to comply with environmental requirements. Therefore penalties should be high enough to enforce compliance so that a company cannot deliberately break the laws and regulations expecting to pay lighter penalties than profits made.

A number of directors are opposed to corporate governance measures with the main reason being that the initiatives slow down decision making and enhance bureaucracy and red tape in business practice. Richard Branson's own experience with the London stock Exchange processes in the mid-1980s demonstrated that excessive corporate governance hindered his decision making, and ability to make things happen [29]. On the positive side, there is developing perception that good corporate governance is associated with prosperous companies in financial [14, 29, 20]. Corporate governance demonstrates company's value and enhances its legitimacy and the credibility of corporate decisions and reporting it makes with respect to its operations. Good corporate governance system can create some degree of competitive advantage in the market place and improve an organizations cohesion, thus reducing agency costs. With good corporate governance, auditing as an essential corporate governance mechanism [14, 29]. Therefore good corporate governance can be used as a tool for gaining competitive advantage in the market with auditing playing a critical role in organizational governance systems.

\section{Conclusion}

Corporate governance is as important to a company as the core business plan is. Good corporate government is a sure way to prevent corporate scandals, fraud and related consequences. It the image or profile of an organization as a self-policing institution. Good corporate governance goes beyond rules and regulations that the government can put in place. It is also about ethics and the values which drive companies in the conduct of their business. Dishonest and unethical dealings can cause shareholders to flee out of fear, distrust and disgust. Implementation of corporate governance mechanisms may require a shift in the existing policies, systems and practices within a business, which would require participatory management, with the emphasis on 'substance over form implementation steps.

Self-regulation has significant advantages because corporate governance requirements tend to increase bureaucracy and red tape which slow down business decision making process and hence efficiency. However, whereas selfregulations looks more attractive for free market economies, legislation and control is necessary since not all managers believe in self-regulation. Where there is good corporate governance, there is a system by which companies are directed and controlled such that boards of directors are in charge of the governance of the organizations. The shareholders' should exercise their power by electing directors and appointing auditors and put in place proper systems of governance as the beginning point of good corporate governance. The board of directors' operations and activities should be guided by laws, regulations and the shareholders.

The Enron Corporation and Volkswagen scandals demonstrate that severe consequences result from failed corporate governance which are both monetary and nonmonetary affecting both perpetrators and the innocent people especially workers. These consequences include jail terms, loss of employment, fines, penalties, bankruptcy, loss of value and investment for investors and severe negative publicly. In the attempt to enforce compliance, legislation or regulations introduce undesirable bureaucracy in business at 
the expense of self-regulation. Where corporate governance fails, major indicators include, manipulation of financial records, corruption, poor quality products and exaggerated quality specifications in manufacturing and engineering, high staff turnover, lack of transparency and accountability, poor stakeholder relationship, poor performance and low economic development leading widespread poverty. To manage governance issues, self-regulation should be encouraged but have as a minimal, external or legal enforcement. This enforcement should be participatory and considerate to genuine stakeholder interests to avoid legislation that will encourage cheating or survival like the case of Volkswagen scandal. But perpetrators of governance failure should be punished both as individually and as organizations or companies like the case of Enron and Volkswagen Corporations to serve as an example. The penalties and fines imposed should be high enough to discourage non-compliance for profit making.

All organizations regardless of the nature of business, whether in manufacturing, retail busness, finance or can be affected by governance failure and should therefore prepare its structures to prevent corporate governance failure.

\section{Findings and Recommendations from the Study}

The study through literature survey and case studies came up with the following findings and recommendations concerning business ethics and corporate governance in business and manufacturing.

i.) Corruption is a result as well as indicator corporate governance failure in organizations and society and should be controlled.

ii.) For good corporate governance to be realized, the board of directors should be in charge of overall leadership and direction of the organization.

iii.) It is hard to separate good corporate governance and ethical values and principles of managers and employees therefore any effort to put in place good corporate governance should be grounded in good ethical standards and principles.

iv.) The consequences of corporate governance failure will always be felt by many and that the problem of corporate governance started many years ago which is reason for all organizations to be concerned from the onset and put in place measures to ensure it is natured.

v.) It is values that lay the foundation of good corporate governance besides institutional arrangements that enhance transparency and accountability in corporate leadership and management, and so institutional arrangements should be put in place to enforce correct value systems within an organization.

vi.) Organizations should create ethical environments through role modelling and consistent and predictable decision making on issues of ethics and morality so as to give direction and avoid ethical dilemmas in the organizations. By so doing, ethical conduct becomes part and parcel of all in the organization.

vii.) Business ethics is dynamic or temporal, hence the guiding principles $t$ may vary over time and so tend to change over time and place. The result is that some practices that are acceptable today may become unacceptable in future as circumstances change. It is therefore recommended that business ethics which form the foundation of good corporate governance should be responsive to changing technology and circumstance. However, the changes must be acceptable to society.

viii.) There is need for business and manufacturing regulations alongside self-regulation in issues or corporate governance because business realities may create circumstances that tempt managers to engage in unethical conduct leading to governance failure and serious consequences. Not all managers believe in ethical principles in business practice.

ix.) Legal imposition of accountability and hence external regulation of businesses was a result of corporate scandals and governance failure that had reached alarming levels. This is undesirable to investors who prefer self-regulation, and therefore organizations should set a higher ethical bar to make external regulations which are undesirable irrelevant.

x.) Good corporate governance should provide rules and regulations that the government and organization but in addition to ethics and the values which drive companies in the conduct of their business

xi.) Employees should not be subjected to unrealistic targets to the extent of forcing them to engage unethical practices through enforcing qualitative targets and enforcing transformational leadership style.

xii.) Organizational leadership has a critical role to play as role models in ethical issues through their day to day actions that reinforce ethics amongst other employees. They should also strictly enforce agreed code of ethics by all stakeholders.

xiii.) Huge investment in developing the EA 89 engine which did not meet environmental standards as set by EPA played a leading role and motivation for the Volkswagen scandal. Therefore research and development effort is risky and expensive, hence the need for companies to be cautious while regulators should accommodate investors in developing realistic regulations subject to availability of technology.

xiv.) The revelation that Volkswagen was involved in unethical tests on $\mathrm{NO}_{2}$ effects on heath young men in Germany and the macaque monkeys is an indicator of corporate governance failure and a company that had developed a culture of unethical conduct which created room for the mega emissions scandal. 
Organizations should never treat unethical issues lightly however small as they build up to big scandals with time.

$\mathrm{xv}$.) Major corporate scandals lead to job losses, loss of shareholders values, huge penalties and fines, expensive product recalls and even company collapse as shown by the Enron and Volkswagen scandals.

xvi.) Therefore beginning point of Enron Corporation collapse was investment in volatile market segments and failure to employ due diligence while making investments. Therefore new investments should be cautiously made with application of due diligence to safeguard investors capital.

xvii.) Enron used financial fraud in the name of mark-tomarket practice, a scheme that were designed to hide the losses and make the company appear more profitable than it really was.

xviii.) Enron auditors failed to expose the fraud and allowed Enron to continue hiding losses till the company could not hide further. This is professional misconduct which should be avoided to prevent governance failure.

xix.) The Enron scandal was financial in nature whereas Volkswagen scandal was technical in nature. Both however lead to significant financial and personal losses. Therefore governance failures can assume pure financial or technical dimension.

xx.) The fact that Enron Corporation enegaged in general trade activities and Volkswagen Corporation engaged in manuafacturing experienced governance failure illustrates that all organizations can fall victim to governance failure and should put in place measures to prevent governance failure regardless of their nature of business.

Therefore governance failure as demonstrated by the Enron and Volkswagen scandals affect the entire industry, nation and global business and regulatory regimes. Individuals and corporates all face consequences. It is therefore necessary to put in place measures that guarantee good corporate governance. This measures are both internal through self-regulation and external through legislation and enforcement. Organizations should preferable go the selfregulation route for better results and greater performance in the areas of corporate governance.

\section{References}

[1] Abid, G. \&Ahmed, A. (2014). Failing in Corporate Governance and Warning Signs of a Corporate Collapse. Pakistan Journal of Commerce and Social Sciences, 8 (3), 846-866. Retrieved from https://www.researchgate.net/publication/270048173

[2] Armitage, K. (2018, July 6). 3 Reasons your business is failing at Corporate Governance. Corporate Compliance Insights. Retrieved from https://www.corporatecomplianceinsights.com/3-reasonsbusiness-failing-corporate-governance/
[3] Boston, W., Varnholt, H., \& Sloat, S. (2015, December). Volkswagen Blames 'Chain of Mistakes' for emissions scandal. The Wall Street Journal. Retrieved from http://www.wsj.com/articles/vw-shares-up-ahead-ofemissionsfindings-1449740759.

[4] Chu, J. (2015, October 28). Study: Volkswagen's emissions cheat to cause 60 premature deaths in U. S., Massachusetts Institute of Technology. Retrieved from http://news.mit.edu/2015/volkswagen-emissions-cheat-cause60-premature-deaths-1029.

[5] David, F. R. (2011). Strategic management concepts and cases. Upper Saddle River, New Jersey: Prentice.

[6] David O. Mbat, D. O. \& Eyo, E. I. (2013). Corporate Failure: causes and remedies. Business and Management Research, 2 (4). 19-24. doi: 10.5430/bmr.v2n4p19.

[7] Dyer, J. H., Godfrey, P., Jensen, R., \& Bryce, D. (2016). Strategic management: Concepts and tools for creating real world strategy. Hoboken, NJ: John Wiley \& Sons.

[8] Emshwiller, J. \& Smith, R. (2001, October 17). Enron jolt: investments, assets generate big loss-part of charge tied to 2 partnerships Interests Wall Street. The Wall Street Journal. Retrieved from https://uvanc.com/03182746.pdf

[9] Ewing, J. (2015, October 4). Volkswagen engine-rigging scheme said to have begun in 2008. The New York Times. Retrieved

https://www.nytimes.com/2015/10/05/business/engineshortfall-pushed-volkswagen-to-Evade-emissions-testing.html.

[10] Ewing, J. (2016, April 22). VW, setting aside \$18 billion for diesel scandal costs, reports record loss. The New York Times. Retrieved from https://www.nytimes.com/2016/04/23/business/international/v olkswagen-loss-emissions-scandal.html

[11] Fernando A.C. (2012). Business Ethics and corporate Governance (2nd Ed.). India: Pearson.Retrieved from https://www.oreilly.com/library/view/business-ethicsand/789332511255/

[12] Friedman, M. (2011, January 27). Goes on Tour. A survey of attitudes to business turns up some intriguing national differences. The Economist. Retrieved from https://www.economist.com/business/2011/01/27/miltonfriedman-goes-on-tour

[13] Friedman, A. L and Miles, S. (2006). Stakeholder's theory and practice, Oxford University Press, Oxford.

[14] Gachie, W. \& Govender, D. W. (2017). Practical application of corporate governance principles in a developing country: A Case Study. Risk Governance \& Control: Financial Markets $\begin{array}{lllll}\& & \text { Institutions, } & 7 & \text { (2), }\end{array}$ http://dx.doi.org/10.22495/rgcv7i2art7

[15] Kabeyi, M. J. B. (2018a). Ethical and unethical leadership issues, cases, and dilemmas with case studies. International Journal of Applied Research. 4 (8), 373-379. http://www.allresearchjournal.com/archives/2018/vol4issue7/ PartF/4-7-6-651.pdf

[16] Kabeyi, M. J. B. (2018b) Transformational Vs Transactional Leadership with Examples. International Journal of Business and Environment. 6 (5), 191-193. Retrieved from https://www.theijbm.com/may-18. 
[17] International Finance Corporation (2009). Practical Guide to Corporate Governance. Author. Retrieved From https://www.oecd.org/corporate/ca/corporategovernanceprinci ples/43653645.pdf.

[18] Ivory, D. \& Jack Ewing, J. (2015, October 7). Volkswagen U. S. Chief Knew of Potential Emissions Problems in 2014. The New York Times https://www.nytimes.com/2015/10/08/business/international/v olkswagen-diesel-emissions-fix.html

[19] King IV (2016, November 1). Draft Report on Governance for South Africa, and the Draft Code of Governance. Retrieved from https://c.ymcdn.com/sites/iodsa.siteym.com/resource/collection/684B68A7-B768-465C8E3A007F15A5A/IoDSA_King_IV_Report__WebVersion.pdf.Principles", Johannesburg: Institute of Directors.

[20] KPMG (2014), Toolkit for the company Director, KPMG. Retrieved from https://betterboards.net/.../2014/.../Better\%20Boards\%20prese ntation-\%20Sally\%20Fre.

[21] Latham, J. R. (2014). Leadership for quality and innovation: Challenges, theories, and a framework for future research. Quality Management Journal, 21 (1), 11-15.

[22] Mansouri, N. (2015). A case study of Volkswagen unethical practice in diesel. Emission TestInternational Journal of Science and Engineering Applications. https://www.ijsea.com/archive/volume5/issue4/IJSEA0504100 4.pdf

[23] McGee, (2017, January 12). VW. Criminal settlement round off years of deceit and denial. Financial Times.

[24] McKay, D. R., Nitsch, R Peters, D. A. (2015). Corporate governance and business ethics. Plast Surg, 23 (4), 271-272. Retrieved https://www.ncbi.nlm.nih.gov/pmc/articles/PMC4664146/

[25] Monks, R. \& Minow, N. (2008). Corporate Governance. Blackwell Publishing. New Jersey.

Mansouri, N. (2016). A case study of Volswagn unethical practice in diesel emission test. International Journal of science and Engineering Applications, 5 (4), 211-216. Retrieved

from https://www.ijsea.com/archive/volume5/issue4/IJSEA0504100 4.pdf

[26] Nainawat, R. \& Meena, R (2013). Corporate governance and business ethics. Global Journal of Management and Business Studies, 3 (10), 1085-1090. Retrieved from http://www.ripublication.com/gjmbs.htm

[27] Odumeru, J. A. \& Ifeanyi, G. O. (2013). Transformational vs. transactional leadership theories: Evidence in literature. International Review of Management and Business Research. 2 (2). 355-361. Retrieved from http://irmbrjournal.com
[28] Segal, T. (2019). Enron scandal: the fall of a Wall Street darling. Investopedia. https://www.investopedia.com/updates/enron-scandalsummary/

[29] Solomon, J. F. \& Solomon, A. (2014). Corporate governance and accountability. John Wiley \& Sons, New Jersey.

[30] Stanwick, P. \& Stanwick, S. (2017). Volkswagen Emissions Scandal: The perils of installing illegal software. International Review of Management and Business Research http://www.irmbrjournal.com/papers/1487585135.pdf

[31] Starrett S. (2011). Examples from Create Your Own Code of Ethics assignment. Retrieved from https://nationalethicscenter.org/resources/308/download/Starre tt_codeofethicsassignment

[32] Sun, L. (n. d.). Why is Corporate Governance Important? Business Dictionary. Retrieved from http://www.businessdictionary.com/article/618/why-iscorporate-governance-important/

[33] Sun, W., Stewart. \& Pollard, D. (2012, February 12). A Systemic Failure of Corporate Governance: Lessons from the On-going Financial Crisis. The European Financial Review https://www.europeanfinancialreview.com/a-systemic-failureof-corporate-governance-lessons-from-the-on-going-financialcrisis/

[34] Sullivan, J. D. (2009, February). The Moral Compass of Companies: Business Ethics and corporate governance as antiCorruption Tools. International Finance Corporation. Retrieved from https://openknowledge.worldbank.org/handle/10986/23980

[35] The Guardiian (2018, February 4). If governments will not punish VW's shocking behavior, consumers must. The Guardian.

https://www.theguardian.com/business/2018/feb/04/volkswag en-shocking-be

[36] Vlasic, B. \& Kessler. A. (2015, September 21). It took EPA. Pressure to get VW to admit faul. The New York Times. https:/www.nytimes.com/2015/09/22/business/it-took-epapressure-to-get-vw-to-admit-Fault.htmlhaviour-punishconsumers-must-punish-it

[37] Yadav, J. B. (n. d). Role of ethics in business and corporate governance. Rexjournals, 3 (3), 319-325. Retrieved from https://www.academia.edu/34653432/ROLE OF ETHICS IN _BUSINESS_AND_CORPORATE_GOVERNA $\bar{N} C E$

[38] Youssef. M. T. (1991). Corporate governance an Overview around the globe. Grant Thornton http://www.eiod.org/uploads/Publications/Pdf/Corp.\%20Gove rnance-1.pdf 